\title{
KARAKTERISTIK HUKUM ACARA PENGADILAN HUBUNGAN INDUSTRIAL
}

\author{
Sugeng Santoso \\ Hakim Pengadilan Hubungan Industrial (PHI) \\ Mahkamah Agung Republik Indonesia \\ E-mail : sgng_aysant@yahoo.com
}

\begin{abstract}
Abstrak
Perselisihan hubungan industrial yang diselesaikan melalui Pengadilan Hubungan Industrial menempatkan pekerja/buruh berhadapan dengan pengusaha dan mendasarkan hukum formalnya pada ketentuan Pasal 57 UU No. 2/2004 yang pada pokoknya menggunakan hukum acara perdata kecuali yang diatur khusus. Penggunaan hukum acara perdata tersebut setelah dianalisis ternyata tidak sesuai dengan hukum perburuhan. Karakteristik hukum acara Pengadilan Hubungan Industrial berbeda dengan hukum acara perdata.
\end{abstract}

Kata kunci : hukum acara; karakteristik; Pengadilan Hubungan Industrial; perbandingan

\begin{abstract}
The Industrial relations dispute which is resolved through the Industrial Relations Court puts the workers/laborers against the employers and bases their formal source of law on the Article 57 of Law No. 2/2004 which basically uses the civil procedure except under special regulation. The analysis in this study shows that the implementation of civil procedure actually contravenes the labor law. The characteristics of the Industrial Relations Court procedure differs from the civil procedure.
\end{abstract}

Keywords: procedural law; characteristics; Industrial Relations Court; Comparison

\section{A. PENDAHULUAN}

Buruh dan pengusaha adalah pelaku utama dalam dunia industri, maka buruh dan pengusaha haruslah bekerja sama dengan baik dan terus menjaga hubungan yang baik diantara keduanya sebagaimana tujuan semula hubungan industrial tersebut diciptakan. Hubungan Industrial yang harmonis antara buruh dan pengusaha diharapkan dapat terus terjadi dan hal tersebut merupakan sinergi untuk mencapai tujuan yang telah ditetapkan oleh organisasi tersebut. Tanpa ada kerja sama yang baik dan hubungan industrial yang harmonis antara buruh dan pengusaha tidaklah mungkin organisasi dalam skala kecil maupun negara dalam skala yang lebih luas akan mencapai apa yang menjadi cita-cita dan harapan organisasi atau sebuah negara dibentuk. Bahkan Amanat dalam alinea keempat Pembukaan Undang-Undang Dasar Negara Republik Indonesia Tahun 1945 menyebutkan bahwa : "kemudian daripada itu untuk membentuk suatu pemerintah Negara Indonesia yang melindungi segenap bangsa Indonesia dan seluruh tumpah darah Indonesia dan untuk memajukan kesejahteraan umum dan keadilan sosial serta dengan mewujudkan suatu keadilan sosial bagi seluruh rakyat Indonesia ". Hal tersebut merupakan tujuan pembangunan di bidang ketenagakerjaan yang juga sebagai bagian dari pembangunan Nasional.

Hubungan hukum antara buruh dan pengusaha tersebut diawali dengan pembuatan perjanjian kerja baik yang dibuat secara tertulis maupun secara lisan. Perjanjian yang berisi hak dan kewajiban tersebut kemudian dalam pelaksanaannya sering muncul permasalahan-permasalahan yang apabila tidak ada saling pengertian ataupun tidak ada kesepahaman dan apabila tidak dapat diselesaikan akhirnya dapat berujung pada timbulnya perselisihan diantara para pihak. Dalam bahasa Inggris istilah yang 
dipergunakan untuk mengartikan perselisihan atau sengketa adalah conflict or dispute. Dispute a conflict or controversy; a conflict of claims or right, claim, or demand on one side, met by contrary claims or allegations on the other. The subject of litigation; the matter for which a suit brought and upon which issue is joined, and in relation to which jurors are called and witnesses axamined. See cause of action; claim, controversy; Justiciable controversy; labor dispute. ${ }^{1}$

Masyarakat memiliki berbagai macam cara untuk menyelesaikan sengketa yang mereka hadapi, mulai dari penyelesaian oleh para pihak secara kooperatif, dengan bantuan orang lain atau pihak ketiga yang bersifat netral dan sebagainya. ${ }^{2}$ Apabila penyelesaian dengan cara-cara sebagaimana tersebut tidak dapat tercapai kesepakatan maka para pihak akan menempuh jalur pengadilan. Khusus terhadap perselisihan yang terjadi antara para pihak dalam hubungan industrial sejak dikeluarkannya Undang-Undang Nomor 2 Tahun 2004 (selanjutnya disebut "UU No. 2/2004") telah dibentuk pengadilan khusus yang dinamakan Pengadilan Hubungan Industrial (selanjutnya disebut "PHI") sebagaimana dirumuskan dalam Pasal 1 angka 17 UU No. 2/2004 : Pengadilan Hubungan Industrial adalah pengadilan khusus yang dibentuk di lingkungan pengadilan negeri yang berwenang memeriksa, mengadili, dan memberi putusan terhadap perselisihan hubungan industrial. Perselisihan hubungan industrial itu sendiri dirumuskan dalam Pasal 1 angka 1 UU No. 2/2004 sebagai perbedaan pendapat yang mengakibatkan pertentangan antara pengusaha dan gabungan pengusaha dengan pekerja/buruh atau serikat pekerja/ serikat buruh karena adanya perselisihan mengenai hak, perselisihan kepentingan, perselisihan pemutusan hubungan kerja dan perselisihan antar serikat pekerja/serikat buruh dalam satu perusahaan.

\footnotetext{
${ }^{1}$ Henry Cambell Black, Black's Law Dictionary, West Publishing Co., St. Paul Minnesota,1979, hlm. 424

${ }^{2}$ Lalu Husni, Penyelesaian Perselisihan Hubungan Industrial Melalui Pengadilan dan di luar Pengadilan, RajaGrafindo Persada, 2005 , hlm. 7
}

Sebagai sebuah lembaga peradilan tentulah PHI juga mempunyai kompetensi yang membedakan dengan lembaga peradilan yang lainnya. Kehadiran PHI tersebut tentulah diharapkan memberikan solusi terhadap sengketa/perselisihan hubungan industrial yang selama ini dirasakan kurang memberikan penyelesaian terbaik bagi pelaku hubungan industrial. Kehadiran PHI sebagaimana diatur dalam UU No. 2/2004 (yang berlaku secara efektif sejak tanggal 15 Januari 2006 melalui Peraturan Pemerintah Pengganti UndangUndang No. 1 Tahun 2005), pada awalnya disambut dengan sangat antusias oleh warga masyarakat terbukti dengan banyaknya gugatan yang diajukan.

Disinyalir pula bahwa dari gugatan yang masuk ke PHI ternyata sebagian besar belum memenuhi syarat dan terdapat kekurangan utama pada persyaratan formal, yakni persyaratan untuk mengajukan suatu gugatan. Padahal kompetensi absolut PHI sebagaimana tercantum dalam Pasal 56 UU No. 2/2004 adalah: PHI bertugas dan berwenang memeriksa dan memutus: a. Di tingkat pertama mengenai perselisihan hak ; b. Di tingkat pertama dan terakhir mengenai perselisihan kepentingan; c. Di tingkat pertama mengenai perselisihan pemutusan hubungan kerja ; d. Di tingkat pertama dan terakhir mengenai perselisihan antar serikat pekerja / serikat buruh dalam suatu perusahaan. Kompetensi absolut PHI yang meliputi empat macam perselisihan tersebut menurut Wijayanto Setiawan menjadikan pertentangan dengan maksud dibuatnya undang-undang. Karakteristik perselisihan perburuhan hanyalah 2 (dua) macam, yakni perselisihan hak (rechtsgeschil, conflick of right) dan perselisihan kepentingan (belangengeschillen, conflick of interest) tidak bisa kurang atau lebih, dan tak akan berubah sampai kapanpun. ${ }^{3}$

Atas dasar rumusan tersebut, perselisihan hubungan industrial mengandung unsur : Pertama, subyek sengketa adalah pekerja /

${ }^{3}$ Wijayanto Setiawan, Pengadilan Perburuhan Indonesia, Laras, Sidoarjo,2007, hlm. 196 
buruh, serikat pekerja / serikat buruh dan pengusaha/gabungan pengusaha, Kedua, obyek sengketa adalah perselisihan hak, perselisihan kepentingan, perselisihan pemutusan hubungan kerja dan perselisihan antar serikat pekerja / serikat buruh dalam suatu perusahaan. Berarti perselisihan hubungan industrial lahir dari adanya hubungan industrial antara para pihak. Sehingga hubungan industrial antara para pihak merupakan conditio sine quanon bagi timbulnya perselisihan hubungan industrial. Tanpa adanya hubungan industrial antara para pihak tidak akan ada sengketa hubungan industrial. Pasal 1 ayat 1 UU No. 2/2004 memformulasikan perselisihan hubungan industrial sebagai : perbedaan pendapat yang mengakibatkan pertentangan antar pengusaha atau gabungan pengusaha dengan pekerja / buruh atau serikat pekerja / serikat buruh karena adanya perselisihan mengenai hak, perselisihan kepentingan, perselisihan pemutusan hubungan kerja dan perselisihan antar serikat pekerja / serikat buruh dalam suatu perusahaan.

PHI yang sudah mulai berlaku efektif sejak tahun 2006 tersebut tentu saja dilengkapi dengan aturan-aturan tentang formalitas untuk beracara di lembaga peradilan. Aturan dan tata cara berperkara dimaksudkan agar para pihak dan siapapun yang terlibat dalam PHI dapat menjalankan peranan fungsinya secara jelas.

Agar dapat memahami hukum acara PHI tidak cukup hanya mempelajari Pasal-Pasal yang tersurat dalam UU No. 2/2004 berikut penjelasannya, tetapi juga harus memahami karakteristik hukum acara PHI. Sebagai contoh adalah hasil Penelitian Penyelesaian Perselisihan Hubungan Industrial melalui Pengadilan Hubungan Industrial oleh Fakultas Hukum Universitas Airlangga tahun 2006, yang dalam salah satu kesimpulannya menyatakan bahwa terdapat disharmonisasi antara UU No. 2/2004 dengan UndangUndang Ketenagakerjaan. Disharmonisasi ini merupakan persoalan yang muncul di luar empat kompetensi absolut Pengadilan
Hubungan Industrial. ${ }^{4}$ Kesimpulan tersebut bersesuaian pula dengan pendapat agar dilakukan revisi Undang-Undang No. 2 Tahun 2004 Tentang Penyelesaian Perselisihan Hubungan Industrial dipandang perlu menjadi prioritas Program Legislasi Nasional yang diawali dalam penyusunan rancangan akademik (naskah akademisi). Melalui revisi dimaksud Undang-Undang menjadi lebih komprehensif, sehingga mampu mencerminkan ratio legis kepastian hukum dan keadilan dalam upaya mewujudkan asas peradilan yang cepat, tepat, adil dan murah yang didasarkan pada nilai-nilai Pancasila. ${ }^{5}$

Atas dasar kenyataan demikian, mengikuti saran di kalangan ahli hukum sehubungan dengan hukum acara PHI, ada beberapa kemungkinan yang dikemukakan :

1. Menggunakan hukum acara yang berlaku di Peradilan Umum dengan penambahan dan pengurangan tanpa ada batas tenggang hukum dan keadilan yang merata.

2. Tidak ada salahnya apabila acara yang dipergunakan dalam persidangan perkara perselisihanhubunganindustrial,digunakan hukum acara yang berlaku bagi perkara perdata.

3. Menciptakan dan menggunakan hukum acara yang khusus diberlakukan untuk PHI. Dari ketiga kemungkinan tersebut, saran terakhir yang lebih sesuai, karena hukum acara sebagai hukum formal semestinya dibuat atas landasan yang diberikan oleh hukum materiilnya masing-masing. Penempatan hukum acara PHI sama dengan hukum acara perdata adalah tidak tepat. Harus disadari bahwa "di muka PHI, materi maupun acaranya haruslah mencerminkan karakteristik tersendiri. Walaupun Pasal 57 UU No. 2/2004 menegaskan bahwa hukum acara yang berlaku pada PHI adalah hukum acara yang berlaku pada pengadilan dalam lingkungan peradilan umum, tidak berarti

\footnotetext{
${ }^{4}$ Machsoen Ali, dkk, Penyelesaian Perselisihan Hubungan Industrial Melalui Pengadilan Hubungan Industrial, Laporan Penelitian Universitas Airlangga,2006, hlm. 37

${ }^{5}$ Christina NM Tobing,Menggagas Pengadilan Hubungan Industrial dalam bingkai Ius Constituendum sebagai upaya perwujudan kepastian hukum dan keadilan, Jurnal Hukum dan Peradilan, Volume 7 No. 2 Juli,2018, hlm. 27
} 
secara otomatis hukum acara perdata dapat diterapkan dalam proses beracara pada PHI. Bukankah hukum acara PHI mempunyai karakteristik tersendiri yang tentunya dapat saja berbeda dengan hukum acara perdata. Dengan demikian pokok masalah yang menarik untuk dikaji adalah : Kekhususan hukum acara PHI.

\section{B. METODE PENELITIAN}

Pada pokoknya tipe penelitian ini adalah penelitian normative. Sebagaimana pendapat Terry Hutchinson : Doctrinal Research - research which provides a systematic exposition of the rules governing a particular legal category, analyses the ralationship between rules, explaints areas of difficulty and, perhaps, predicts future developments ;

Theoritical Research: research which fosters a more complete understanding of the conceptual bases of legal principles and of the combined effects of a range of rules and procedures that touch on a particular area of actifity. ${ }^{6}$ Relevansi antara doctrinal research dengan legal research paradigm dikemukalan lebih lanjut oleh Terry sebagai berikut : "Paradigm forms a model or pattern based on a set of rules that defines bounderies and specifies how to be successful within those bounderies. $^{7}$ Pendekatan yang digunakan adalah statute approach, dan conceptual approach.

\section{PEMBAHASAN}

Hukum Acara PHI merupakan hukum formal yang pada hakekatnya termasuk dalam hukum perdata. Sebagaimana disebutkan dalam Pasal 57 UU No. 2/2004 bahwa hukum acara yang berlaku pada PHI adalah hukum acara yang berlaku pada pengadilan dalam lingkungan peradilan umum, kecuali yang diatur secara khusus dalam Undang-undang ini.

6 Terry Hutchinson, Reseaching and Writing in Law, Lawbook. Co, Queensland University,2002, hlm. 9

${ }^{7}$ Ibid., hlm. 10-11
Di dalam hukum perdata, keterkaitan antara hukum formal dengan hukum materiil adalah sebagaimana yang dikemukakan oleh Bos :8

Het materiele recht regelt relaties tusses personen (...) Als zulke regels overtreden worden, moet er iest gebeuren : het materiele recht moet 'gehandhaafd' worde, moet er iest gebeureb : het materiele recht moet 'gehandhaafd' worden en dat gebeurt in een proces. Zo'n proces is zelft weer geregeld en die regels heten 'formeel recht' (Hukum materiil mengatur hubungan antar manusia (...). Apabila aturan-aturan semacam itu dilanggar, maka harus terjadi sesuatu: hukum materiil harus ditegakkan dan hal itu terjadi di dalam suatu acara. Acara tersebut diatur dan aturan-aturannya disebut 'hukum formal').

Patut kita simak pendapat Sjahran Basah yang memasukkan hukum formal menjadi salah satu unsur peradilan di samping hukum materiilnya. Rochmat Soemitro mengemukakan pula tentang unsur-unsur peradilan yang akan menjadi tidak memiliki validitas teoritis dan praktis (theoretical and practical validity) selama hukum formal tidak ditambahkan sebagai salah satu unsur peradilan. ${ }^{9}$ Berikut tabel perbandingan unsurunsur Peradilan yang dikemukakan oleh Suparto Wijoyo : ${ }^{10}$

8 Purnadi Purbacaraka dan Soerjono Soekanto, Aneka Cara Pembedaan Hukum, Bandung: Alumni, 1980,hlm. 2829

${ }^{9}$ Rochmat Soemitro, Masalah Peradilan Administrasi Dalam Hukum Pajak di Indonesia, Cetakan keempat, Eresco, Bandung, 1989, hlm. 4-6

${ }^{10}$ Suparto Wijoyo, Karakteristik Hukum Acara Peradilan Administrasi, Cetakan kedua, Airlangga University Press, 2005, hlm. 15

14 Sugeng Santoso | Kekhususan Hukum Acara Pengadilan.... 
Tabel 1. Unsur-unsur Peradilan pada umumnya

\begin{tabular}{|c|c|}
\hline $\begin{array}{c}\text { Menurut Rochmat } \\
\text { Soemitro }\end{array}$ & $\begin{array}{c}\text { Menurut Sjachran } \\
\text { Basah }\end{array}$ \\
\hline $\begin{array}{l}\text { a. adanya suatu } \\
\text { aturan hukum } \\
\text { yang abstrak } \\
\text { yang mengikat } \\
\text { umum, yang dapat } \\
\text { diterapkan pada } \\
\text { suatu persoalan; } \\
\text { b. adanya suatu } \\
\text { p e r s e li s i h a n } \\
\text { hukum yang } \\
\text { konkret; } \\
\text { c. ada sekurang- } \\
\text { kurangnya dua } \\
\text { pihak; } \\
\text { d. adanya suatu } \\
\text { aparatur peradilan } \\
\text { yang berwenang } \\
\text { m e m u t u s k a n } \\
\text { perselisihan. }\end{array}$ & 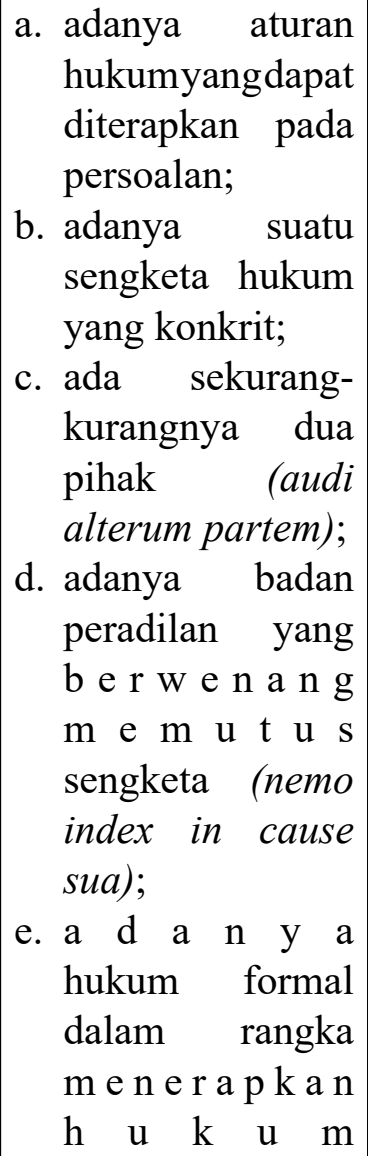 \\
\hline
\end{tabular}

Keterangan : Unsur (a) sampai dengan (d) sama, sedang unsur (e) merupakan tambahan.

Penambahan unsur e [adanya hukum formal dalam rangka menerapkan hukum (rechtstoepassing) dan menemukan hukum (rechtsvinding) "in concreto" untuk menjamin ditaatinya hukum materiil] didasarkan atas alasan guna menjamin menjadi terlaksananya unsur-unsur peradilan dari huruf a sampai d. Memang peradilan tanpa hukum materiil akan lumpuh Karena tidak tahu apa yang akan dijelmakannya, sebaliknya peradilan tanpa hukum formal akan liar sebab tidak ada batas-batas yang jelas dalam melakukan wewenangnya. ${ }^{11}$ Dengan demikian, hukum acara yang dikenal pula sebagai hukum proses mengatur penegakkan hukum yang materinya telah ditentukan dalam hukum materiilnya. Namun, hal ini tidak berarti bahwa keseluruhan hukum acara hanya berisikan

\footnotetext{
${ }^{11}$ Rochmat Soemitro, Op.cit, hlm. 31
}

hukum tentang pelaksanaan teknik beracara. Dalam hukum acara juga ditemukan hukum materiil yang berisikan hak-hak para pihak yang beracara. Hukum acara sebagai hukum formal mengandung pula unsur materiil maupun formal. Unsur materiil hukum acara dalam kepustakaan hukum (Belanda) senantiasa disebut 'actienrecht" (substantive law of procedure), merupakan ketentuan yang mengatur hubungan hukum yang terjadi karena beracara, sebagaimana contoh tentang Hukum acara perdata hanya diperuntukkan menjamin ditaatinya hukum perdata meteriil dengan perantaraan hakim. ${ }^{12}$

1. Terjadi dan hapusnya tuntutan hak atau gugatan.

2. Upaya-upaya hukum untuk menangkis atau menyangkal.

3. Upaya-upaya untuk menegakkan hukum atau hak.

4. Pengaruh tindakan-tindakan prosesuil

5. Pembuktian

6. Menjatuhkan putusan.

Formal hukum acara mengatur tentang cara yang harus diperhatikan dalam beracara, yakni mengatur tentang caranya menggunakan wewenang seperti ditentukan dalam unsur materiil, misalnya tentang bagaimana caranya mengajukan banding. Atas dasar kedua unsur itulah hukum acara pada prinsipnya mengatur pelaksanaan penyelesaian perkara (sengketa) demi kepentingan dan ketentraman warga masyarakat agar tindakan "eigenrichting" dapat dicegah.

Hukum acara dalam kepustakaan hukum dikenal pula dengan nama hukum ajektif sebagai pasangan hukum substantif. Penyebutan demikian didasarkan pada pertimbangan untuk tidak menjumbuhkan dengan adanya penyebutan terhadap perbedaan antara hukum acara materiil (materiele procesrecht) dan hukum acara formal (formele procesrecht). Hukum ajektif oleh Henry Campbell Black diartikan sebagai berikut :13

\footnotetext{
${ }^{12}$ Sudikno Mertokusumo, Hukum Acara Perdata Indonesia, Cetakan Pertama, Liberty, Yogyakarta, 1993,hlm. 2

${ }^{13}$ Henry Cambell Black, Op. Cit., p. 38, dalam edisi 1991, hlm. 25-26
} 
Adjective Law : The aggregate of rule of procedure of practice. As opposed to that body of law which the courts are established to administer (called 'substantive law'), it means the rule according to which the substantive law is administrated,... That part of the law which provides a method for enforcing or maintaining rights, or obtaining redress for their invasion... Pertians to and prescribes practice, method, procedure or legal machinery by which substantive law is enforced or made effective.

Substantive law didefinisikan seperti berikut : ${ }^{14}$

The part of law which creates, defines, and regulates rights, as apposed to 'adjective of remedial law', which prescribes method of enforcing the right or obtaining redress for their invasion. That which creates duties, right and obligations, which procedural or remedial law'. Prescribes methods of enforcement of right or obtaining redress... The basic law of right and duties (...) as opposed procedural law (...)

Berdasarkan rumusan di atas dapat dipahami bahwa hukum acara sebagai hukum formal dengan demikian merupakan penuntun normative dalam menertibkan dan mendayagunakan peradilan, termasuk dalam hal ini adalah hukum acara Pengadilan Hubungan Industrial. PHI agar dapat menjalankan fungsinya maka mutlak memerlukan adanya ketentuan hukum acara yang diberlakukan atau diterapkan pada $\mathrm{PHI}$ tersebut.

Pada hakekatnya sifat hukum acara adalah mengabdi kepada hukum materiil. Hukum acara PHI sudah seharusnya sifatnya harus mengabdi pula kepada hukum perburuhan yang merupakan hukum materiilnya. Hukum perburuhan itu mempunyai karakteristik yang berbeda dengan hukum perdata. Akibat adanya karakteristik yang berbeda tersebut, secara "parsial" pengabdian hukum formal terhadap materiilnya membawa spesifikasi

\footnotetext{
${ }^{14}$ Ibid., 1991, hlm. 1281-hlm.1997
}

tersendiri sebagai sifat khas acaranya seperti terangkum dalam tabel berikut :

Tabel 2. Sifat Hukum Acara PHI dan Hukum

\begin{tabular}{|c|c|c|c|}
\hline \multicolumn{4}{|c|}{ Acara Perdata } \\
\hline No. & Uraian & $\begin{array}{c}\text { Hukum Acara } \\
\text { Peradilan Hubungan } \\
\text { Industrial }\end{array}$ & $\begin{array}{l}\text { Hukum } \\
\text { Acara Per- } \\
\text { data }\end{array}$ \\
\hline 1. & $\begin{array}{l}\text { Tolak } \\
\text { ukur } \\
\text { pangkal } \\
\text { sengketa } \\
\text { : Obyek }\end{array}$ & $\begin{array}{l}\text { Pekerja/buruh x } \\
\text { Pengusaha/ } \\
\text { Serikat pekerja/bu- } \\
\text { ruh x Pengusaha/ga- } \\
\text { bungan pengusaha } \\
\text { Serikat pekerja/bu- } \\
\text { ruh x Serikat peker- } \\
\text { ja/buruh dalam satu } \\
\text { perusahaan } \\
\text { (sebagaimana keten- } \\
\text { tuan Pasal } 1 \text { angka } \\
1 \text { UU No. } 2 \text { Tahun } \\
\text { 2004) } \\
\text { Perselisihan hak; } \\
\text { Perselisihan kepent- } \\
\text { ingan; } \\
\text { Perselisihan PHK; } \\
\text { Perselisihan antar } \\
\text { SP/SB dalam satu } \\
\text { perusahaan } \\
\text { (sebagaimana keten- } \\
\text { tuan Pasal } 56 \text { UU } \\
\text { No. } 2 \text { Tahun 2004) } \\
\text { Hukum Perburuhan }\end{array}$ & $\begin{array}{l}\text { Warga } \\
\text { masyarakat } \\
\mathrm{x} \text { warga } \\
\text { masyarakat } \\
\text { Warga } \\
\text { masyarakat } \\
\mathrm{x} \text { badan } \\
\text { atau pejabat } \\
\text { adminis- } \\
\text { trasi }\end{array}$ \\
\hline
\end{tabular}

Sumber : UU No. 2/2004 dan dari berbagai sumber

Sifat hukum acara PHI memiliki kekhususan dibandingkan dengan sifat hukum acara perdata. Dalam hukum acara PHI terdapat tolok ukur subyek dan tolok ukur pangkal atau obyek sengketa. Tolok ukur subyek yaitu pihak yang bersengketa adalah antara Pekerja/buruh, Serikat pekerja/buruh dengan Pengusaha/gabungan pengusaha, ataupun dengan Serikat pekerja/buruh lain dalam satu perusahaan, yang keduanya harus didengar (audi alteram partem atau eines 
mannes rede ist keines mannes rede, man soll sie horen alie beide - kedua belah pihak harus didengar). Tolok ukur obyek sengketa ialah Perselisihan antara pihak yang meliputi : Perselisihan hak, Perselisihan kepentingan, Perselisihan PHK dan Perselisihan antar SP/ SB dalam satu perusahaan. Bentuk obyek sengketa di luar keempat perselisihan tersebut dan yang bertalian dengan tindakan menurut hukum perdata, apabila menimbulkan sengketa akan masuk menjadi kompetensi Peradilan Umum.

Sifat khas hukum acara perdata sesuai dengan asas-asasnya, menurut Sudikno Mertousumo adalah : ${ }^{15}$

1. Hakim bersifat menunggu.

yaitu inisiatif untuk mengajukan tuntutan hak diserahkan sepenuhnyakepada yang berkepentingan... Kalau tidak ada tuntutanhakataupenuntutan, makatidakada hakim (Wo kein Klager ist, ist kein Richter; nemo judex sine actore).

2. Hakim pasif

Hakim di dalam memeriksa perkara perdata bersifat pasif dalam arti kata bahwa ruanglingkupatauluas pokok sengketayang diajukankepadahakimuntukdiperiksapada asasnya ditentukan oleh para pihak yang berperan dan bukan oleh hakim.

3. Sifat terbukanya persidangan

Sidang pemeriksaan pengadilan pada asasnya adalah terbuka untuk umum, yang berarti bahwa setiap orang dibolehkan hadir dan mendengarkan pemeriksaan di persidangan.

4. Mendengar kedua belah pihak.

Di dalam hukum acara perdata kedua belah pihak haruslah diperlakukan sama, tidak memihak dan didengarbersama-sama.

5. Putusan harus disertai alasan-alasan.

Semua putusan pengadilan harus memuat alasan-alasan putusan yang dijadikan dasar untuk mengadili.

6. Beracara dikenakan biaya.

7. Tidak ada keharusan mewakilkan.

Memahami secara seksama tentang asasasas hukum acara perdata tersebut akan

\footnotetext{
${ }^{15}$ Sudikno Mertokusumo, Op. Cit., hlm. 9-16
}

menimbulkan pemikiran kritis bahwa tidaklah mudah untuk menerapkan ketentuan yang menggariskan bahwa hukum acara Peradilan Hubungan Industrial menggunakan hukum acara perdata yang berlaku pada peradilan umum meskipun dengan pengecualianpengecualian.

Kesulitan dalam penerapan tersebut sesungguhnya bersumber dari karakteristik hukum acara PHI yang tercermin dalam asas-asas hukum perburuhan yang melandasi hukum acara PHI. Mengenai asas-asas hukum perburuhan termaksud antara lain :

a. Asas perlindungan hukum. asas ini mengandung makna pihak pekerja/ buruh sebagai pihak yang lemah dalam berhadapan dengan pengusaha atau dan perlu mendapatkan perlindungan sehingga tidak terjadi tindakan sewenang-wenang.

b. Asas kesetaraan/kesejajaran kedudukan pekerja dan pengusaha. Asas ini menempatkan dua pihak dalam hubungan industrial dalam posisi yang sama.

Asas-asas hukum perburuhan tersebut lebih menempatkan posisi dan maksud diadakannya PHI sebagai perbandingan adalah maksud diadakannya Peradilan Administrasi. Menurut Van Galen dan Van Maarseven yang dikutip oleh Suparto Wijoyo, sesuai dengan maksud Peradilan Administrasi, yaitu :16 "het bieden van (rechts-) bescherming tegen bestuurshandelingen" - memberikan perlindungan hukum terhadap tindak pemerintahan", asas-asas hukum administrasi yang merupakan "karakteristieken" hukum acara Peradilan Administrasi adalah :

a. Actieve rechter (hakim aktif)

b. Ongelijkheidscompensatie (kompensasi karena ketidaksamaan kedudukan)

c. Uniteitsbeginsel (asas kesatuan);

d. Non-cumulatie (non komulasi/ penumpukan);

e. Vrij bewijs (pembuktian bebas);

f. Procesmondigheid (penanganan secara lisan);

${ }^{16}$ Suparto Wijoyo, Op. Cit., hlm. 21-22 
g. Vermoeden van rechtmatigheid (praduga rechtmatig - praduga "sah" prakiraan atas keabsahan).

Sesuai dengan kompetensi absolut PHI menurut Undang-undang No. 2/2004, sebagai implikasi dan konsekuensi yuridis-teoritisnya adalah tercerminnya asas-asas hukum perburuhan tersebut dalam ketentuan hukum acara PHI dalam menyelesaikan perselisihan hubunganindustrial.Penyelesaianperselisihan hubungan industrial oleh PHI berdasarkan UU No. 2/2004 tetaplah terikat pada asasasas hukum perburuhan yang melandasi hukum acara PHI. Perselisihan hubungan industrial merupakan sengketa di bidang hukum perburuhan yang lahir sebagai akibat pelaksanaan hukum perburuhan oleh pelaku hubungan industrial, sehingga seharusnyalah apabila penyelesaiannya berpijak pada asas-asas hukum perburuhan. Ini penting artinya, sebab hukum acara mengatur tata cara penegakan hukum yang materinya telah ditetapkan dalam hukum materiilnya. Hukum acara (formal) merupakan sarana untuk melaksanakan hukum materiil. Penegakan hukum materiil oleh hukum formal secara konkret berlangsung saat berlakunya hukum positif dalam praktek sebagai keharusan yang patut ditaati. Oleh karena itu, memberikan keadilan dalam suatu perselisihan hubungan industrial berarti memutus sengketa dengan menerapkan hukum, menemukan hukum in concreto dalam upaya mempertahankan dan menjamin ditaatinya hukum materiil sebagai hukum in abstracto dengan prosedur yang ditetapkan oleh hukum formal. Dapat pula dikatakan bahwa fungsi utama hukum acara Peradilan Hubungan Industrial menurut UU No. 2/2004 adalah merealisasikan hukum in abstracto menjadi hukum in concreto yang mengikat para pihak yang bersengketa dalam rangka menyelesaikan perselisihan hubungan industrial.

Ketentuan hukum acara PHI dalam UU No. 2/2004 terdapat pada Pasal 81 sampai dengan Pasal 115. Sehingga komposisi ketentuan yang mengatur tentang penyelesaian perselisihan hubungan industrial dan termasuk hukum acaranya adalah sebagaimana tampak pada tabel berikut :

Tabel 3. Ketentuan UU No. 2/ 2004

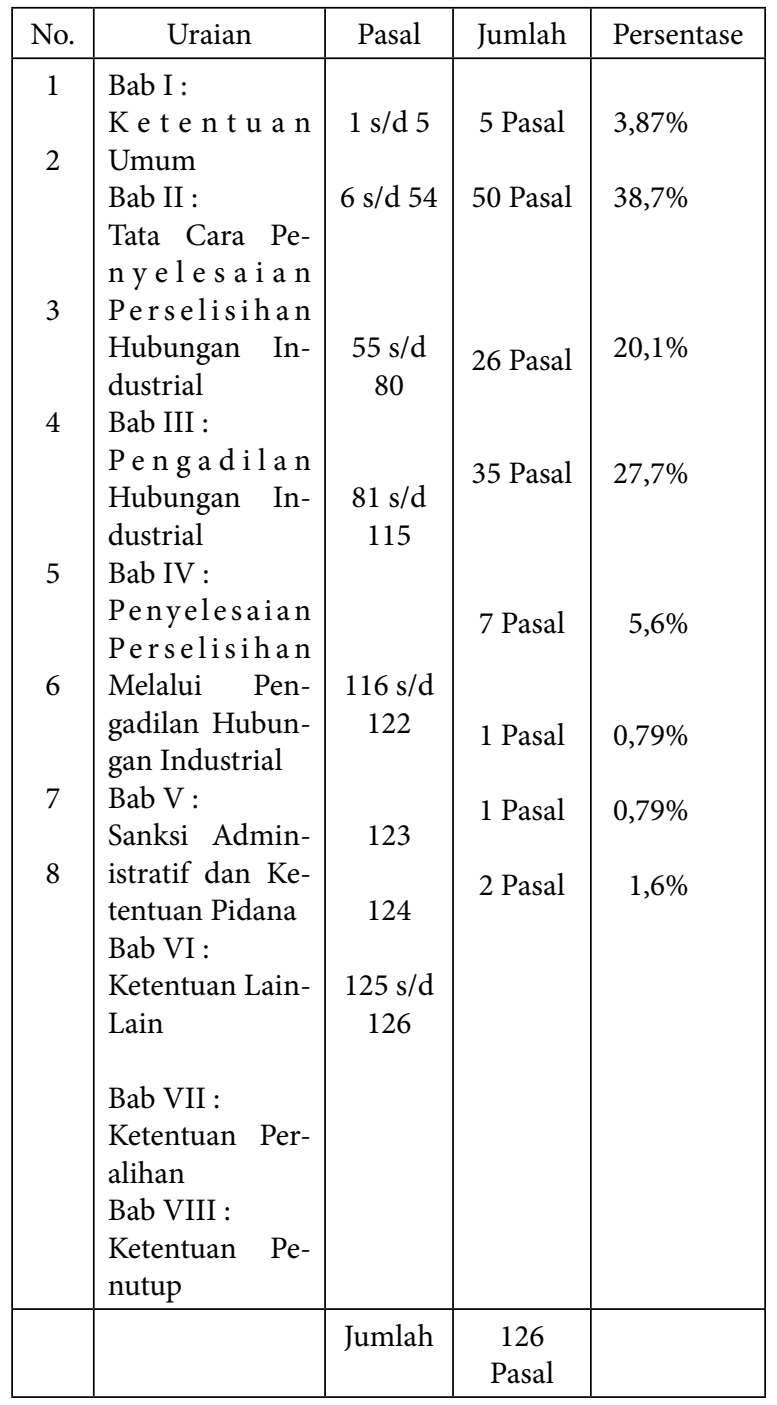

Sumber : UU No. 2/2004

UU No. 2/2004 yang didalamnya termuat pengaturan mengenai hukum acara dan Undang-Undang Nomor 13 Tahun 2003 (yang selanjutnya disebut "UU No. 13/2003") yang merupakan pengaturan sebagian dari hukum materiil tentang hukum perburuhan dapat saja diberlakukan, sebab cara pengaturan hukum acara dalam hukum positif dapat dikelompokkan menjadi dua bagian, yaitu :

1. Ketentuan prosedur berperkara diatur tersendiri masing-masing dalam bentuk undang-undang atau bentuk peraturan lainnya. 
2. Ketentuan prosedur berperkara diatur bersama-sama dengan hukum materiilnya atau dengansusunan, kompetensi daribadan yang melakukan peradilan dalam bentuk undang-undang atau peraturan lainnya.

Undang Nomor 2 Tahun 2004 mengikuti kelompok yang pertama dalam memberikan pengaturan mengenai hukum perburuhan diatur secara khusus dalam UU No. 13/2003 tentang Ketenagakerjaan dan peraturanperaturan ketenagakerjaan lainnya. Pasal 136 ayat (2) UU No. 13/2003 telah menyatakan :

Dalam hal penyelesaian secara musyawarah untuk mufakat sebagaimana dimaksud dalam ayat (1) tidak tercapai, maka pengusaha dan pekerja/buruh atau serikat pekerja/serikat buruh menyelesaikan perselisihan hubungan industrial melalui prosedur penyelesaian perselisihan hubungan industrial yang diatur dengan undang-undang.

Dalam ketentuan Pasal 57 UU No. 2/2004 yang menyebutkan bahwa hukum acara yang berlaku pada PHI adalah hukum acara yang berlaku pada pengadilan dalam lingkungan peradilan umum, kecuali yang diatur secara khusus dalam undang-undang ini. Beberapa pengecualian hukum acara yang dimaksud adalah :

a. Peradilan Hubungan Industrial merupakan peradilan khusus yang berada pada lingkungan peradilan umum, susunan hakimnya terdiri dari hakim karir dan hakim ad hoc.

b. Ada 4 (empat) perselisihan

c. Perkara yang nilai gugatannya kurang dari Rp. 150.000.000,- para pihak dibebaskan dari biaya perkara termasuk eksekusi.

d. Gugatan diajukan kepada PHI yang daerah hukumnya meliputi tempat pekerja bekerja.

e. Gugatan oleh pekerja atas tidak diterimanya pemutusan hubungan kerja, dapat diajukan hanya dalam tenggang waktu satu tahun sejak diterimanya atau diberitahukannya keputusan dari pihak pengusaha.

f. Upaya perundingan wajib dilakukan.

g. Hakim berkewajiban memeriksa isi gugatan dan bila terdapat kekurangan, hakim meminta penggugat untuk menyempurnakan.

h. Dalam hal perselisihan hak dan/atau perselisihan kepentingan diikuti dengan perselisihan pemutusan hubungan kerja, pengadilan wajib memutus terlebih dahulu perkara perselisihan hak dan/atau perselisihan kepentingan.

i. Serikat Pekerja dan Organisasi Pengusaha dapatbertindak sebagaikuasahukum, untuk mewakili anggotanya.

j. Mengenal dua macam cara pemeriksaan, yaitu : dengan acara biasa dan dengan acara cepat.

k. Apabila dalam persidangan pertama secara nyata-nyata pihak pengusaha terbukti tidak melaksanakan kewajibannya membayar upah selama skorsing, majelis hakim harus segera menjatuhkan putusan sela berupa perintah untuk membayar upah dan hakhak pekerja lainnya, memerintahkan sita jaminan, danputusanitutidakdapatdiajukan perlawanan.

1. Adanyaketentuanwaktu penyelesaianyang harus dilaksanakan.

$\mathrm{m}$. Sidang sah apabila dilakukan oleh majelis hakim.

Ketentuan tersebut, ternyata telah menimbulkan interpretasi yang keliru, seakanakan hukum acara PHI merupakan hukum acara Perdata. Para pencari keadilan terbagi menjadi dua kelompok, ada para pihak yang terlibat proses beracara dalam menyelesaikan perselisihan hubungan industrial cenderung mengedepankan pemahaman bahwa hukum acaranya identik dengan hukum acara perdata, dan sebaliknya ada pihak yang lebih menonjolkan perbedaan prisipal lainnya, yakni adanya karakteristik yang ada dalam hukum acara PHI.

Hukum acara PHI menurut UU No. 2/2004 hendaklah dikaji secara mendalam. Apalagi telah disinyalir bahwa hukum acara PHI belum dipahami secara baik, dan juga tidak kalah penting ialah kesadaran pengusaha dalam mematuhi putusan PHI. Memahami dan menyadari akan adanya kekhususan 
dan bahkan perbedaan antara hukum acara PHI dengan hukum acara perdata dalam menyelesaikan perselisihan hubungan industrial di badan PHI menurut UU No. 2/2004 adalah mutlak.

Berikut perbandingan hukum acara perdata dan hukum acara PHI yang penulis simpulkan dalam bentuk tabel :

Tabel 4 : Perbandingan Hukum Acara Perdata dan Hukum Acara PHI

\begin{tabular}{|c|c|c|}
\hline $\begin{array}{l}\text { Perbandin- } \\
\text { gan }\end{array}$ & $\begin{array}{l}\text { P e r a dila n } \\
\text { Umum }\end{array}$ & $\begin{array}{l}\text { Pengadilan Hubun- } \\
\text { gan Industrial }\end{array}$ \\
\hline $\begin{array}{l}\text { M a j e l i s } \\
\text { Hakim }\end{array}$ & $\begin{array}{ll}\text { Tidak men- } \\
\text { genal Hakim } \\
\text { Adhoc }\end{array}$ & $\begin{array}{l}\text { Harus } 3 \text { orang ter- } \\
\text { diri dari } 1 \text { (satu) } \\
\text { Hakim karir seba- } \\
\text { gai ketua, } 2 \text { (dua) } \\
\text { Hakim Adhoc (dari } \\
\text { SP/SB dan APIN- } \\
\text { DO) (Psl } 55 \text { dan } 60 \\
\text { UU 2/2004) }\end{array}$ \\
\hline $\begin{array}{l}\text { M a c a m } \\
\text { Perselisihan }\end{array}$ & $\begin{array}{l}\text { Hanya } 2 \\
\text { macam : wan- } \\
\text { prestasi dan } \\
\text { perb a t a n } \\
\text { melawan hu- } \\
\text { kum }\end{array}$ & $\begin{array}{l}\text { Ada } 4 \text { (empat) } \\
\text { macam perselisihan } \\
\text { : Hak, Kepentingan, } \\
\text { PHK, antar SP/SB } \\
\text { dalam } 1 \text { perusahaan } \\
\text { (Psl 56 UU 2/2004) }\end{array}$ \\
\hline $\begin{array}{l}\text { Tingkatan } \\
\text { penyelesa- } \\
\text { ian }\end{array}$ & $\begin{array}{l}\text { Ada upaya hu- } \\
\text { kum : Banding } \\
\text { \& Kasasi }\end{array}$ & $\begin{array}{l}\text { Tidak ada Banding } \\
\text { dan hanya perselisi- } \\
\text { han Hak \& PHK } \\
\text { yg bisa dilakukan } \\
\text { kasasi (Psl } 56 \text { UU } \\
\text { 2/2004) }\end{array}$ \\
\hline $\begin{array}{l}\text { Pengajuan } \\
\text { Gugatan }\end{array}$ & $\begin{array}{l}\text { Diajukan di } \\
\text { tempat tinggal } \\
\text { tergugat (Psl } \\
142 \text { HIR) }\end{array}$ & $\begin{array}{l}\text { Diajukan ke PHI } \\
\text { di tempat dimana } \\
\text { pekerja/buruh bek- } \\
\text { erja (Psl. } 81 \text { UU } \\
\text { 2/2004) }\end{array}$ \\
\hline $\begin{array}{l}\text { Upaya pe- } \\
\text { nyelesaian } \\
\text { s e b e l u m } \\
\text { pengadilan }\end{array}$ & $\begin{array}{l}\text { Perundingan } \\
\text { \& upaya per- } \\
\text { damaian wajib } \\
\text { dilakukan teta- } \\
\text { pi tidak harus } \\
\text { ada bukti dan } \\
\text { gugatan tetap } \\
\text { diperiksa (Psl } \\
130 \text { HIR) }\end{array}$ & $\begin{array}{l}\text { Wajib dilakukan } \\
\text { Mediasi/ konsiliasi } \\
\text { tanpa bukti telah } \\
\text { dilakukan mediasi/ } \\
\text { konsiliasi maka gu- } \\
\text { gatan dikembalikan } \\
\text { (Psl } 83 \text { ayat (1) UU } \\
\text { 2/2004) }\end{array}$ \\
\hline
\end{tabular}

\begin{tabular}{|c|c|c|}
\hline $\begin{array}{l}\text { Kewajiban } \\
\text { Hakim ter- } \\
\text { hadap guga- } \\
\text { tan }\end{array}$ & $\begin{array}{l}\text { Tidak ada ke- } \\
\text { wajiban hakim } \\
\text { tetapi Ketua } \\
\text { PN dapat } \\
\text { memberikan } \\
\text { nasehat dalam } \\
\text { pe m bu a ta n } \\
\text { gugatan un- } \\
\text { tuk kelancaran } \\
\text { (Psl } 119 \text { \& } 132 \\
\text { HIR) }\end{array}$ & $\begin{array}{l}\text { Memeriksa dan jika } \\
\text { ada kekurangan } \\
\text { minta Penggugat } \\
\text { menyempurnakan } \\
\text { (Psl } 83 \text { ayat (2) UU } \\
\text { 2/2004) }\end{array}$ \\
\hline $\begin{array}{l}\text { P e ng g - } \\
\text { b u n g a n } \\
\text { Perselisi- } \\
\text { han/seng- } \\
\text { keta }\end{array}$ & $\begin{array}{l}\text { Tidak ada ke- } \\
\text { wajiban Pen- } \\
\text { gadilan me- } \\
\text { mutus terlebih } \\
\text { dahulu }\end{array}$ & $\begin{array}{l}\text { Perselisihan hak/ } \\
\text { kepentingan yg dii- } \\
\text { kuti perselisihan } \\
\text { PHK, PHI memutus } \\
\text { perselisihan hak/ } \\
\text { kepentingan terle- } \\
\text { bih dahulu (Psl } 86 \\
\text { UU 2/2004) }\end{array}$ \\
\hline $\begin{array}{l}\text { Macam aca- } \\
\text { ra pemerik- } \\
\text { saan }\end{array}$ & $\begin{array}{l}\text { Tidak dikenal } \\
\text { pemeriksaan } \\
\text { dengan acara } \\
\text { cepat }\end{array}$ & $\begin{array}{l}\text { Ada } 2 \text { (dua) macam } \\
\text { pemeriksaan bi- } \\
\text { asa (Psl } 89 \text { s/d } 97 \\
\text { UU 2/2004) dan } \\
\text { pemeriksaan cepat } \\
\text { (Psl } 98 \text { s/d } 99 \text { UU } \\
2 / 2004)\end{array}$ \\
\hline $\begin{array}{l}\text { P u t u s a n } \\
\text { Sela }\end{array}$ & $\begin{array}{l}\text { Putusan sela } \\
\text { dapat dimin- } \\
\text { takan banding } \\
\text { (Psl } 185 \text { ayat } \\
\text { (1) dan Psl } 190 \\
\text { ayat (1) HIR) }\end{array}$ & $\begin{array}{l}\text { Dikenal Putusan } \\
\text { sela yg tidak bisa di- } \\
\text { ajukan perlawanan } \\
\text { (Psl } 96 \text { UU 2/2004) }\end{array}$ \\
\hline $\begin{array}{l}\text { A d a n y a } \\
\text { ketentuan } \\
\text { waktu pe- } \\
\text { nyelesaian }\end{array}$ & $\begin{array}{l}\text { Ke te n t u a n } \\
\text { waktu dilaku- } \\
\text { kan secara in- } \\
\text { ternal (SK Ket- } \\
\text { ua Mahkamah } \\
\text { Agung) }\end{array}$ & $\begin{array}{l}\text { Majelis Hakim men- } \\
\text { jatuhkan putusan } \\
\text { paling lama } 50 \text { hari } \\
\text { (Psl } 103 \text { UU } 2 / 2004 \text { ) }\end{array}$ \\
\hline $\begin{array}{l}\mathrm{S} \text { i d a } \mathrm{n} g \\
\text { harus ma- } \\
\text { jelis }\end{array}$ & $\begin{array}{l}\mathrm{D} \text { i m u } \mathrm{ng}- \\
\text { kinkan si- } \\
\text { dang dengan } \\
\text { hakim tung- } \\
\text { gal (ijin Ketua } \\
\mathrm{M} \text { a h k a m a h } \\
\text { Agung) }\end{array}$ & $\begin{array}{ll}\text { Sidang sah apabila } \\
\text { dilakukan } & \text { Majelis } \\
\text { Hakim (Psl } & 92 \text { UU } \\
\text { 2/2004) } & \end{array}$ \\
\hline
\end{tabular}




\begin{tabular}{|c|c|c|}
\hline $\begin{array}{l}\text { B i a y a } \\
\text { perkara }\end{array}$ & $\begin{array}{l}\text { Ada biaya } \\
\text { perkara kecua- } \\
\text { li berperkara } \\
\text { dengan prodeo } \\
\text { dengan syarat2 } \\
\text { tertentu. } \\
\text { PERMA SCC } \\
\text { (Small claim } \\
\text { court)/PER- } \\
\text { MA No. } 2 \text { thn } \\
2015 \text { - guga- } \\
\text { tan materiil } \\
<200 \text { juta }\end{array}$ & $\begin{array}{l}\text { Nilai gugatan di } \\
\text { bawah Rp. } 150 \text { juta } \\
\text { tidak dikenakan bi- } \\
\text { aya }\end{array}$ \\
\hline $\begin{array}{l}\text { Kuasa } \mathrm{Hu}- \\
\text { kum }\end{array}$ & $\begin{array}{l}\text { Hanya pengac- } \\
\text { ara/Advokat } \\
\text { yang bisa men- } \\
\text { jadi penasehat } \\
\text { hukum (Psl } 31 \\
\text { UU 18/2003) }\end{array}$ & $\begin{array}{l}\text { Serikat pekerja/seri- } \\
\text { kat buruh dan or- } \\
\text { ganisasi pengusaha } \\
\text { dapat bertindak se- } \\
\text { bagai kuasa hukum } \\
\text { untuk beracara di } \\
\text { pengadilan Hubun- } \\
\text { gan industrial untuk } \\
\text { mewakili anggot- } \\
\text { anya. } \\
\text { (Psl } 87 \text { UU 2/2004) }\end{array}$ \\
\hline
\end{tabular}

Sumber : UU No. 2/2004 dan dari berbagai sumber

\section{Kekhususan Hukum Acara PHI}

Pasal 57 UU No. 2/2004 menentukan bahwa, hukum acara yang berlaku pada PHI adalah Hukum Acara Perdata yang berlaku pada Pengadilan dalam lingkungan Peradilan Umum kecuali yang diatur secara khusus dalam UU No. 2/2004. Untuk itu perlu diketahui mengenai apa saja hukum acara yang diatur dalam UU No. 2/2004 secara khusus, dan mana yang berlaku hukum acara perdata umum.

Hukum acara yang diatur secara khusus dalam Undang-Undang Nomor 2 Tahun 2004 tersebut menurut penulis merupakan kekhususan hukum acara pada PHI yang berbeda dengan hukum acara perdata, antara lain adalah sebagai berikut :

1. Susunan Majelis Hakim. PHI merupakan peradilan khusus yang berada pada lingkungan peradilan umum, susunan hakimnya bersifat tripatit, terdiri dari hakim karir dan hakim ad hoc (Pasal 55 dan 60 UU No. 2/2004, sedangkan dalam hukum acara perdata tidak mengenal hakim ad hoc yang diusulkan oleh Serikat Pekerja dan Organisasi Pengusaha (wakil dari kalangan yang akan berperkara).

2. Ketentuan tentang kompetensi absolut tentang macam-macam perselisihan dan kewenangan penyelesaiannya: a) ditingkat pertama perselisihan hak dan perselisihan PHK, dan b) ditingkat pertama dan terakhir perselisihan kepentingan dan perselisihan antar Serikat Pekerja/Serikat Buruh dalam satu perusahaan. Hukum acara perdata tidak mengenal macam-macam perselisihan dan tidakmembatasiperkaratertentuuntuktidak dapat dilakukan upaya hukum banding/ kasasi. Karakteristik tentang macammacam perselisihan dan kewenangan PHI merupakan hal yang berbeda dalam penerapan asas Pengawasan putusan lewat kasasi. Dalam PHI hanya perselisihan hak dan perselisihan Pemutusan Hubungan Kerja yang dapat dilakukan pengawasan melalui Mahkamah Agung. Putusan PHI Pada Pengadilan Negeri hanya dapat dilakukanupayahukummelaluikasasitetapi hanyapadaperselisihanhakdanperselisihan Pemutusan Hubungan Kerja yang dapat dilakukan upaya hukum kasasi. Terhadap perselisihan kepentingan dan perselisihan antar Serikat Pekerja/Serikat Buruh dalam satuperusahaantidak dapatdilakukanupaya hukum kasasi sebagaimana ketentuan Pasal 56 Undang-Undang Nomor 2 Tahun 2004.

3. Ketentuan tentang biaya perkara. Perkara yang nilai gugatannya kurang dari 150 juta rupiah para pihak dibebaskan dari biaya perkara termasuk eksekusi (Pasal 58 UU No. 2/2004). Sepintas pembagian nilai gugatan tidak menimbulkan masalah. Sesungguhnya pembagian nilai gugatan itu tetap menyimpan masalah dalam praktik. ${ }^{17}$ Hukum acara perdata menentukan : asas peradilan dengan membayar biaya yang dalam hal ini adalah Penggugat membayar biaya perkara, kelak biaya dimaksud menjadi kewajiban pihak yang kalah dalam

17 Juanda Pangaribuan,Tuntunan Praktis Penyelesaian Perselisihan Hubungan Industrial, Edisi Revisi, Edisi Pertama, BIS, Jakarta,2010, hlm. 144 
berperkara. Bagi yang tidak mampu dapat dibebaskan dari membayar biaya perkara dengan memenuhi syarat-syarat tertentu. Pada asas hukum acara perdata sengketa yang diajukan ke pengadilan dikenakan biaya. Dalam PHI berdasarkan Pasal 58 Undang-Undang Nomor 2 Tahun2004yang menentukanbahwahanyagugatanyangnilai gugatannya diatas Rp. 150.000.000,-. Rasio legis dari ketentuan tersebut adalah sebagai bentuk perlindungan kepada pekerja/buruh yangdalamperselisihanhubunganindustrial tentu saja ada pada posisi yang lemah.

4. Ketentuan tentang kompetensi relatif berupa tempat pengajuan gugatan di tempat dimana pekerja/buruh bekerja. Gugatan diajukan kepadaPHIyang daerahhukumnyameliputi tempat pekerja bekerja (Pasal 81 UU No. 2/2004. Ketentuan dalam hukum acara perdata adalah sebagaimana asas actor sequitur forum rei : gugatan dilakukan ditempat tinggal tergugat, apabila tidak diketahui, gugatan dilakukan ditempat tinggal penggugat. Atau gugatan dapat dilakukan di tempat tinggal yang dipilih dalamperjanjian(Pasal142HIRdan 118RBg).

5. Ketentuan tentang tenggang waktu pengajuan gugatan/daluwarsa. UU No. 2/ 2004 menentukan bahwa gugatan oleh pekerja atastidakditerimanyaPemutusanHubungan Kerja, dapat diajukan hanya dalamtenggang waktu satu tahun sejak diterimanya atau diberitahukannya keputusan dari pihak pengusaha(Pasal82UUNo.2/2004). Dalam hukum acara perdata pada dasarnya tidak mengenal daluwarsa dalam beracara.

6. Ketentuan adanya risalah perundingan. Upaya perundingan dalam perselisihan hubungan industrial wajib dilakukan, tanpa bukti perundingan, instansi ketenagakerjaan yang akan mencatatkan perselisihan, akan mengembalikan berkasnya. Demikian pula yang berlaku di PHI, hakim PHI wajib mengembalikan gugatan kepada pengugat, jika gugatan yang tidak dilampiri risalah penyelesaian melalui mediasi atau konsiliasi. Risalah maupun anjuran hanya berfungsi sebagai tiket masuk PHI. ${ }^{18}$ Upaya penyelesaian diluar pengadilan, wajib ditempuh,kalautidakgugatandikembalikan (Pasal 3, 4 dan 83 ayat (1) UU No. 2/2004). Ketentuantentangadanyarisalahperundingan atau di PHI adalah ketentuan tentang adanya risalah penyelesaian melalui mediasi atau konsiliasi, dengan dasar pemikiran bahwa :

Penyelesaian yang diharapkan adalah penyelesaian di luar pengadilan, sebagaimana ditentukan dalam Pasal 36 ayat (1) Undang-Undang No. 13 Tahun 2003 juncto Pasal 3 ayat (1) UU No. 2/2004.

Hukum acara perdata menentukan bahwa perundingan dianjurkan dan diupayakan pada setiap tingkat penyelesaian, namun hakim tidak boleh menolak suatu perkara.

7. Ketentuan adanya dismissal process. Pasal 83 ayat (2) UU No. 2/2004 menentukan bahwa Hakim berkewajiban memeriksa isi gugatandanbilaterdapatkekurangan, hakim meminta pengugat untuk menyempurnakan gugatannya. Hukum acara perdata tidak ada ketentuan yang mewajibkan kepada hakim untuk melakukan hal yang demikian, dalam hukum acara perdata hanya dikenal adanya ketentuan bahwa Ketua Pengadilan dapat memberi nasehat dan bantuan dalam pembuatan gugatan guna kelancaran penyelesaian perkara (Pasal 119 dan 132 HIR, dan Pasal 156 RBg). Dalam hukum acara perdata dikenal Asas Hakim yang Pasif (Lijdelijkeheid van de Rechter) dan oleh karena dalam PHI dikenal adanya ketentuan dismissal process maka hal tersebut menunjukkan karakteristik yang berbeda dengan hukum acara perdata.

8. Ketentuan tentang adanya dua perselisihan yang bersamaan. Pasal 86 UU No. 2/2004 menentukan bahwa dalam hal perselisihan hak dan/atau perselisihan kepentingan diikuti dengan perselisihan pemutusan hubungan kerja, PHI wajib memutus

\footnotetext{
${ }^{18}$ Juanda Pangaribuan, Op.cit., hlm. 132
} 
terlebih dahulu perkara perselisihan hak dan/ atau perselisihan kepentingan. Dalam hukum acara perdata tidak dikenal adanya kewajiban pengadilan untuk memutus terlebih dahulu sengketa yang satu terhadap sengketa yang lainnya.

9. Ketentuan tentang kuasa hukum. Dalam UU No. 2/2004 memberikan kelonggaran terhadap Serikat Pekerja dan Organisasi Pengusaha untuk dapat bertindak sebagai sebagaikuasahukum, mewakilianggotanya (Pasal 87 UU No. 2/2004). Hukum acara perdata menentukan: Setiap orang yang dengan sengaja menjalankan pekerjaan profesi advokat dan bertindak seolaholah sebagai advokat, tetapi bukan advokat, memberikan jasa hukum berupa memberikan konsultasi hukum, bantuan hukum, menjalankan kuasa, mewakili, meridampingi, membela, dan melakukan tindakan hukum lain untuk kepentingan hukum klien, dapat dipidana penjara lima tahun dan denda paling banyak lima puluh jutarupiah(Pasal31UUNo. 18Tahun2003).

10. Ketentuan tentang macam-macam pemeriksaan. UU No. 2/ 2004 mengatur dua macam acara pemeriksaaan, yaitu: a) dengan acara biasa (Pasal $89 \mathrm{~s} / \mathrm{d} 97$ UU No. 2/2004 dan b) dengan acara Cepat (Pasal 98 s/d 99 UU No. 2/2004. Dalam hukum acara perdata tidak mengenal pemeriksaan dengan acara cepat.

11.Ketentuan tentang Putusan Sela. Pasal 96 UU No. 2/ 2004 menentukan bahwa apabila dalam persidangan pertama secara nyata-nyata pihak pengusaha terbukti tidak melaksanakan kewajibannya membayar upah selama skorsing, majelis hakim harus segera menjatuhkan putusan sela berupa perintah untuk membayar upah dan hak-hak pekerja lainnya, memerintahkan sitajaminan, dan putusan itu tidak dapat diajukan perlawanan. Dalam hukum acara perdata tidak ada kewajiban hakim untuk mengeluarkan putusan sela dalam menyelesaikan sesuatu perkara. Dalam prakteknya putusan sela diucapkan di dalam persidangan, namun tidak dibuat secara terpisah, tetapi hanya ditulis dalam berita acara persidangan. Putusan sela dapat dimintakan banding bersama-sama dengan permintaan banding terhadap putusan akhir (Pasal 185 ayat (1), Pasal 190 ayat (1) HIR dan Pasal 20 ayat (1), Pasal 196 ayat (1) Rbg, dan Pasal 48 dan Pasal 332 Rv). Secara normatif dan praktik tidak mengenal secara baku dan tegas bagaimana memeriksa tuntutan provisionil. Karena tidak ada pemeriksaan tuntutan provisionil secara baku, ketentuan praktik peradilan kini bergantung pada pandangan dan kebijakan hakim yang menangani perkara apakah dengan mengeluarkan putusan sela yang menerima atau menolak ataukah menangguhkan hal itu setelah memeriksa pokok perkara ataukah putusan tersebut hanya disinggung selintas dalam putusan akhir. ${ }^{19}$

12. Ketentuan waktu penyelesaian yang harus dilaksanakan/dipatuhi oleh pejabat yang melakukan kekuasaan kehakiman, berupa :

a). Dalam waktu paling lama tujuh hari kerja setelah menerima gugatan, Ketua PN harus sudah menetapkan majelis hakim (Pasal 88 ayat (1) UU No. 2/2004);

b). Dalam waktu paling lambat tujuh hari kerja sejak ditetapkannya majelis hakim, ketua majelis hakim harus sudah melakukan sidang pertama(Pasal89ayat (1) UU No. 2/2004);

c). Apabila salah satu pihak tidak dapat menghadiri sidang, hari sidang berikutnya paling lama dilakukan tujuh harikerja sejaktanggal penundaan(Pasal 93 ayat (1) UU No. 2/2004);

d). Dalamwaktu palinglama tujuh harikerja setelah menerima gugatan yang cukup mendesak dari pemohon (pemeriksaan dengan acara cepat), Ketua PN menetapkan dikabulkan atau ditolaknya permohonan tersebut (Pasal 98 ayat (2) UU No. 2/2004);

${ }^{19}$ Lilik Mulyadi,Kompilasi Hukum Perdata Prespektif Teoritis dan Praktik Peradilan, Alumni, Bandung,2009, hlm. 70 
e). Tenggang waktu untuk jawaban dan pembuktiandarikeduabelahpihakdalam pemeriksaan dengan acara cepat, tidak boleh melebihi 14 hari kerja (Pasal 99 ayat (2) UU No. 2/2004);

f). Majelishakimwajibmemberikanputusan paling lama 50 hari kerja terhitung sejak sidang pertama (Pasal 103 UU No. 2/2004);

g). Panitera pengganti harus memberikan pemberitahuanputusanpalinglama 7hari kerjasetelah putusandibacakan(Pasal105 UU No. 2/2004);

h).Paniteramudaharusmenerbitkiansalinan putusan paling lama 14 hari kerja setelah putusan ditandatangani (Pasal 105 UU No. 2/2004);

i). Panitera harus mengirimkan salinan putusan paling lama 7 hari kerja setelah salinan putusan diterbitkan (Pasal 107 UU No. 2/2004);

j).PutusanPengadilanmempunyaikekuatan hukumtetapapabilatidakdiajukankasasi paling lama 14 kerja setelah diputus/ diterima putusan (Pasal 110 UU No. 2/2004);

k). Sub Kepaniteraan harus sudah menyampaikan berkas permohonan kasasi kepada MA paling lama 14 hari kerja setelah menerima permohonan kasasi (Pasal 112 UU No. 2/2004);

1). Penyelesaian perselisihan hak atau PHK padaMApalinglama30harikerja setelah permohonan diterima(Pasal 115 UUNo. 2/2004);

Dalam hukum acara perdata pada umumnya diatur secara internal berdasarkan SK Ketua MA, kecuali proses kakasi ke MA (Pasal 46 s/d 34 UU. No. 14 Tahun 1985 jo. UU No. 5 Tahun 2004).

13.Ketentuantentangsidangyangsah.UndangUndang Nomor 2 Tahun 2004 menentukan bahwa sidang sah apabila dilakukan oleh majelis hakim (Pasal 92 UU No. 2/2004). Dalam hukum acara perdata masih dimungkinkansidangdenganhakimtunggal berdasarkan izin dari Ketua MA.
14. Tidakadanyaupayahukumbanding. Dalam UU No. 2/ 2004 tidak mengenal adanya upaya hukum banding yang tentu saja hal ini merupakan karakteristik hukum acara di PHI yang berbeda dengan asas hukum acara perdata bahwa Pemeriksaan dalam 2 instansi. Sebagaimana ketentuan dalam UU No.2/2004makaterhadap putusanPHIPada Pengadilan tidak ada upaya banding tetapi hanya dapat dilakukan upaya hukum yaitu melalui kasasi di Mahkamah Agung. Hal ini berbeda dengan asas hukum acara perdata yang berpedoman pada pemeriksaan dalam 2 instansi (Onderzoek in Twee Instanties) artinya jika salah satu pihak atau para pihak keberatan dengan putusan pengadilan tingkat pertama maka dapat mengajukan bandingkepengadilantinggidanselanjutnya pengadilan tinggi akan memeriksa kembali perkara di pengadilan tingkat pertama.

\section{KESIMPULAN}

Hukum Acara di PHI didasarkan pada ketentuan Pasal 57 UU No. 2/ 2004 bahwa hukum acara yang berlaku pada PHI adalah hukum acara yang berlaku pada pengadilan dalam lingkungan peradilan umum, kecuali yang diatur secara khusus dalam undangundang ini. Pengaturan secara khusus dalam UU No. 2/2004 adalah merupakan kekhususan hukum acara di PHI.

\section{DAFTAR PUSTAKA}

Ali, Machsoen, dkk, Penyelesaian Perselisihan Hubungan Industrial Melalui Pengadilan Hubungan Industrial, Laporan Penelitian Universitas Airlangga, 2006;

Black, Henry Compbell, Black's Law Dictionary. West Publishing Co, St. Paul, MN, USA, 1979;

Black, Henry Compbell, Black's Law Dictionary. West Publishing Co, St. Paul, MN, USA, 1991;

Husni, Lalu, Penyelesaian Perselisihan 
Hubungan Industrial Melalui

Pengadilan dan di luar Pengadilan, RajaGrafindo Persada, 2005;

Hutchinson, Terry, Reseaching and Writing in Law, Lawbook. Co, Queensland University, 2002

Mertokusumo, Sudikno, Hukum Acara Perdata Indonesia, Cetakan Pertama, Liberty, Yogyakarta, 1993;

Mulyadi, Lilik, Kompilasi Hukum Perdata Prespektif Teoritis dan Praktik Peradilan, Alumni, Bandung, 2009;

Pangaribuan, Juanda, Tuntunan Praktis Penyelesaian Perselisihan Hubungan Industrial, Edisi Revisi, Edisi Pertama, BIS, Jakarta, 2010;

Purbacaraka, Purnadi dan Soerjono Soekanto, Aneka Cara Pembedaan Hukum, Alumni, Bandung, 1980;

Setiawan, Wijayanto, Pengadilan Perburuhan Indonesia, Laras, Sidoarjo, 2007;

Soemitro, Rochmat, Masalah Peradilan Administrasi Dalam Hukum Pajak di Indonesia, Cetakan keempat, Eresco, Bandung, 1989;

Tobing, Christina NM, Menggagas Pengadilan Hubungan Industrial dalam bingkai Ius Constituendum sebagai upaya perwujudan kepastian hukum dan keadilan, Jurnal Hukum dan Peradilan, Volume 7 No. 2 Juli 2018;

Wijoyo, Suparto, Karakteristik Hukum Acara Peradilan Administrasi, Cetakan kedua, Airlangga University Press, 2005; 